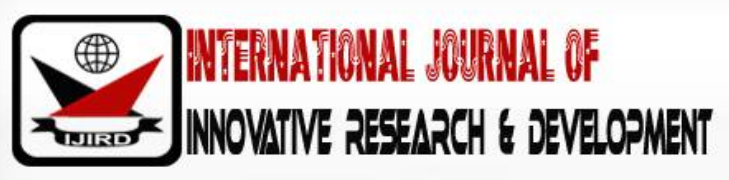

ISSN 2278 - 0211 (Online)

\section{Interest Rate Deregulation and Dynamics of Industrial Sector's Productivity in Nigeria}

\author{
Johnbosco Chukwuma Ozigbu \\ Port Harcourt, Rivers State University, Nigeria
}

\begin{abstract}
:
The systematic deregulation of interest rate in Nigeria in 1987 has continued to generate unending controversies among policy makers and other key stakeholders about its spill-over effects on sectoral performance and economy wide aggregate. In view the growing controversies, this paper analyzed the long-term implication of interest rate deregulation on the productivity of the industrial sector in Nigeria between 1987 and 2016. Specifically, this paper focused attention on the impacts of prime lending rate, deposit rate, monetary policy rate and cash reserve ratio on industrial output. The datasets on each of the variables were culled from the Central Bank of Nigeria Statistical Bulletin. The Autoregressive Distributive Lag (ARDL) model was adopted for the estimation of the long run behavior of the exogenous variables. The Augmented Dickey-Fuller (ADF) stationarity test approach and ARDL based bounds test approach to cointegration were applied to test the null hypotheses of a unit root and no long run relationship respectively. It was found from the ADF tests results that the variables are fractionally integrated. The bounds test result also indicates that the variables are long run relationship, hence necessitating the rejection of the null hypothesis of no cointegration. The long run regression result shows that at 10 percent level, prime lending is positively related to industrial output. This finding is in contrary to the theoretical expectations. It was equally uncovered from the result that monetary policy rate negatively impacted on industrial output at 5 percent level. Similarly, the deposit rate contracts the productivity of the industrial sector in the long run. In of these findings, this paper recommends among others that the Central Bank of Nigeria should ensure that interest rate deregulation is frequently monitored and primarily tailored towards ensuring that the prevailing market rate of interest provides opportunity for improved performance of the industrial sector.
\end{abstract}

\section{Introduction}

The variability of interest rate in a deregulated regime has been identified in literature as having far-reaching implications on the performance of the industrial sector and economy wide aggregate. Ajilore (2015) argues that interest plays an important role in the determination of the value of financial instruments, thus influencing the behavior of economic agents in terms of making three core decisions of consumption, savings and investment. As a tool for monetary policy and credit control, interest rate tends to affect the level and direction of economic activities. Interest rate is often perceived as a germane factor for investment in the economy either by influencing the cost of capital, access to credit or by accelerating the level of savings (Ojo, 2014).

The Keynesian model assumes that interest rate provides the channel through which monetary policy affect aggregate demand. Deregulation of interest rate was originally conceived by McKinnon (1973) as having the potential to engender economic growth through increase in investment. The use of expansionary monetary policy to drive interest rate below its equilibrium level often lead to increase in the price level in the medium term (Imoisi et al, 2012). This could trigger the cost of production with adverse effect on productivity. It is noteworthy that the financial challenges firms pass through in the industrial sector due common occurrence negative profit makes borrowing a perquisite for investment. Again, given the assumption that invested fund are borrowed, the marginal efficiency of investment (MEI) assumes that the functional relationship between investment and interest rate determines the profitability of any investment. Thus, it becomes imperative to maintain a moderately low interest rate to boost profitability and improve industrial sector's performance.

The effectiveness of interest rate manifests in providing required environment for sustainable growth and development of the industrial sector (Nweze, 2010). Rapid industrial development has been described by Adegbie and Adeniji (2013) as the core of economic development. Interest rate policy is often used to increase the availability of credit to the industrial sector in order to stimulate socio-economic development. In Nigeria, interest rate has continued to vary before and after the adoption of Structural Adjustment Programme (SAP). The financial repression that characterized the Nigerian 
economy in 1980s led to the prevalence of interest rate control which generated adverse effects on the level of investment. Notably, interest rate was deregulated in 1987 following the adoption of Structural Adjustment Programme by the Federal government in 1986. Among the reasons for the deregulation of interest rate was to allow for the flow of funds for investment purposes, especially in the industrial sector. Proponents of interest rate deregulation argue that its potential gain lies in allowing for the free functioning of the market forces of demand and supply and promoting the availability of credit to the industrial sector (Calomiris and Himmelberg, 1995).

It is expected that the performance of the industrial sector in Nigeria will be enhanced with the deregulation of interest. Towase (2012) asserts that the rationale for interest rate deregulation as provided by the SAP is to relieve government of its financial burden and engender sustainable growth of industrial sector and overall productivity of the Nigerian economy. However, this kept many on the doubt as the contribution of the industrial sector to the gross domestic product and capacity utilization has continued to fluctuate. For Instance, Edeme and Karimo (2014) opine that the contribution of the industrial sector to gross domestic product in 2008 stood at 3.4 percent, but increased dramatically to 5.6 percent in 2010. The Central Bank of Nigeria (2012) also reports that the growth of the industrial sector stood at 1.2 percent while that of agricultural sector averaged of 5.7 percent between 2010 and 2011.

Besides the fluctuations in the contributions of industrial sector to economy wide aggregate, the share of capacity utilization in the Nigerian industrial sector has also varied overtime. The capacity utility utilization reached an all-time high of 78.70 percent in the late 1970s, before declining to 43.8 percent in the 1980s (Simeon-Oke, 2010). Despite the deregulation of interest rate in Nigeria, the domestic industrial sector seems to perform below expectation, thus intensifying the controversy on the effectiveness of the deregulation of interest rate which is associated with the SAP in driving the growth of industrial sector in Nigeria. It is against this backdrop; this study explores the long-term implication of interest rate deregulation on industrial sector productivity in Nigeria between 1987 and 2016.

\subsection{Statement of the Problem}

The deregulation of interest rate in Nigeria imposed costs on the productive activities of the industrial sector due continuous rise in the market rate of interest. It is important to note that interest rate provides the medium for the linkage of the financial sector to the real sector. High interest tends to discourage borrowing for investment purposes (Acha and Acha, 2011). The actualization of desired interest rate that will stimulate the activities of the industrialists and overall economic growth in Nigeria has remained a major challenge. The CBN has employed various monetary policy tools to ensure the availability of investment accommodating-interest rate. This has necessitated changes in monetary policy rate (MPR) which generates indirect effect on the prevailing interest rate. Since its introduction in 2007, the MPR has been characterized by inconsistencies in its implementation process. This often translates to upward trend in the interest rate with adverse implication on the level of investment. Additionally, the prevalence of informal financial sector in Nigeria tends to constrain the effectiveness of deregulated interest rate to stimulate industrial growth (Towase, 2012). Inconsistencies in government policies in Nigeria have also been identified to limit the effectiveness of interest rate deregulation. This could impair the actualization of interest rate target set by the Monetary Policy Committee (MPC).

Aside the fluctuations in the rate of interest, the dualistic nature of the Nigerian financial system poses a great challenge to the effectiveness of interest rate as a driving force for the sustainability domestic investment. The severe collateral conditions coupled with rising cost of borrowing makes industrial expansion difficult as firms' access to loans and other financial advances are very limited. Poor infrastructure and inadequate inputs and capital goods equally pose a challenge to the productivity and efficient performance of the industrial sector. Thus, industrialists in Nigeria often encounter great difficulty in actualizing the ultimate goal of profit maximization in the regime of deregulated rate of interest. This has remained a major source of concern to stakeholders in the Nigerian economy, thus provoking further inquiry into the effectiveness of interest rate deregulation in stimulating the productivity capacity of the industrial sector in Nigeria.

\section{Literature Review}

\subsection{Review of Theoretical Literature}

\subsubsection{Loanable Funds Theory}

The loanable funds theory was developed by the neoclassical economists. This theory assumes that the determination of interest rate is predicated on changes in demand and supply of loanable funds. Robertson and Pigou among other neoclassical economists elaborated the loanable funds theory. For the neoclassical theorists, interest rate is the price of credit which depends on the demand and supply of loanable funds. The neoclassical theorists categorized demand for loanable funds into three sources comprising the government, investors and consumer.

The demand for fund by the government or public sector is for the provision of public goods which the private sector cannot provide effectively and efficiently or at all. Investor's demand for loanable funds is for purchase of inputs and other capital goods required for boosting the level of production. Borrowings by investors for productive purposes are interest elastic and depend largely on the expected rate of profit relative to the level of interest rate (Ajilore, 2015). Similarly, the 
demand for loanable funds by consumers for durable goods is interest elastic. Consumers' willingness to borrow tends to decline with rising levels of interest rate. Generally, the demand for loanable fund is a negative function of rate of interest.

The supply of loanable funds by both private individuals and corporate savings are interest elastic. Increase in the rate of interest tends to increase the propensity to save and in turn the supply of funds. Additionally, the purchase of old assets or securities from initial owners often regarded as dishoarding equally serve as source of loanable fund. Thus, hoarding of funds tends to reduce with an increase in the prevailing rate of interest and vice versa. Moreover, bank credit represents an important source of loanable fund supply. It depends largely on the rate of interest. Increase in rate of interest provides incentive for banks to increase the amount of loanable funds. The major drawbacks of the loanable funds theory are its unrealistic assumption of full employment and unsatisfactory linkage of real and monetary factors.

\subsubsection{Keynesian Liquidity Preference Theory}

The liquidity preference theory is pioneered by John Maynard Keynes. In his seminal work "The General Theory of Employment, Interest and Money", Keynes classified interest rate as a monetary phenomenon. Specifically, in the view Keynes, interest rate involves the reward for parting with liquidity for a given period of time. According to Keynes, the demand for and supply of money govern the rate of interest. The supply of money which measure aggregate quantity of money available in an economy is assumed to be perfectly inelastic. This stems from the role of the monetary authorities in fixing the quantity of money available in the economy. The liquidity preference theory developed by Keynes is mainly applicable to demand for money. It specifically measures the desire to hold money. Higher liquidity preference requires higher interest rate in order to induce holders of cash to part with the liquid assets (Ajilore, 2015). If no interest is payable to cash holders as an inducement to part with their liquid assets, the tendency of keeping their savings in cash will be very high. Therefore, the higher the rate of interest, the more likely people are to forgo their liquid assets and in turn more funds would be made available for borrowing. The desire to hold cash in the Keynesian perspectives follows three motives which include transactions motive, precautionary motive and speculative motive. The transaction motive involves demand for money to meet daily needs. It is further segmented into income and business motives. While income motive is concerned with demand for money to meet personal needs due to the gap between the receipt and disbursement of income, business motive involves the demand for money to bridge the interval between the time of incurring business costs and receipt of revenue from sales. The precautionary motive is required to provide for emergency situations while the speculative motive involves holding money in order to take advantage of interest-bearing assets. Keynes posits that transactions and precautionary motives for holding money are income elastic. The demand for money for transaction and precautionary purposes tends to increase with an increase in the level of income.

Contrarily, the speculative demand for money is interest elastic. Thus, speculative demand for money is a negative function of interest rate. This can be illustrated using liquidity preference curve as depicted in Figure 1.

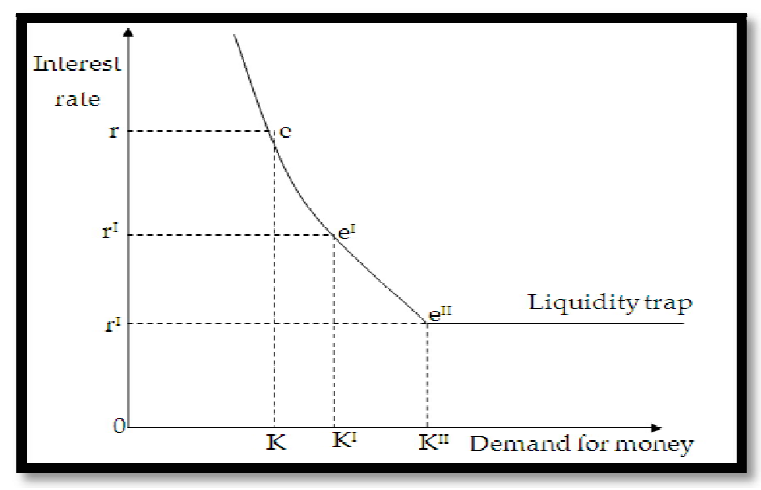

Figure 1: Liquidity Preference Curve

Figure 1 shows that the speculative demand for money increases as the rate of interest decrease. This is evident from the downward sloping of the liquidity preference curve. However, at point "eII" the curve becomes perfectly elastic due to very low interest rate. This perfectly elastic portion of the liquidity preference curve is referred to as the 'liquidity trap' which measures the decision of cash holders to keep any amount of money as inactive balances. The liquidity preference theory suffered setback as it seems to ignore the effect of real factors in determining the rate of interest by regarding interest rate as solely monetary phenomenon.

\subsection{3 .Marginal Efficiency Theory}

The marginal efficiency hypothesis assumes that investment decision of firms is a function of marginal efficiency of investment (MEI) and market rate of interest. Thus, the acquisition of capital by firms depends on the comparison between marginal efficiency of investment and market rate of interest. Investment is considered profitable from the marginal efficiency 
criterion if the marginal efficiency of investment is equal to or greater than the market rate of interest and vice versa. The linkage between marginal efficiency of investment and the rate of interest is demonstrated geometrically in Figure 2.

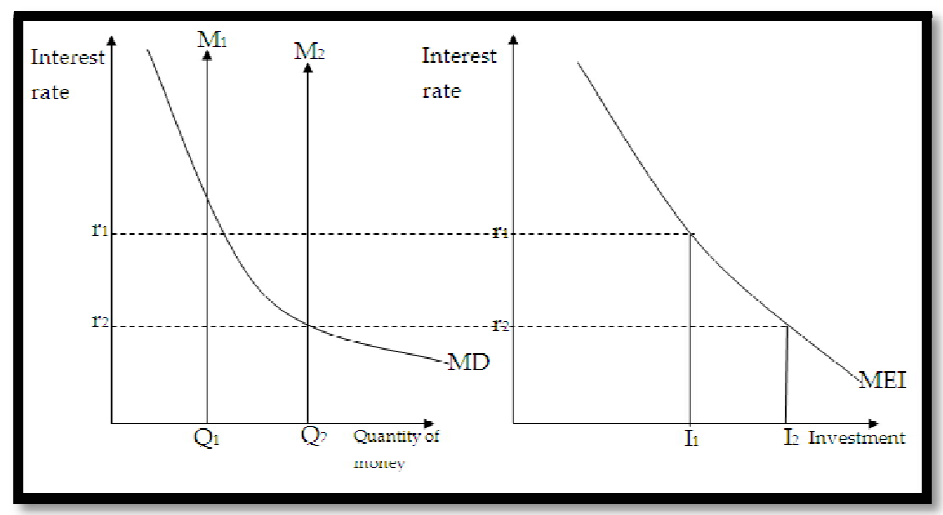

Figure 2: Interest Rate and Marginal Efficiency of Investment (MEI)

Figure 2 indicates that the decision of the monetary authorities, especially central banks to increase money supply causes an outward shift of the money supply curve from $M_{1}$ to $M_{2}$. This induces a fall in interest rate from $r_{1}$ to $r_{2}$ with the demand for money remaining unchanged. The decline in the equilibrium rate of interest will stimulate the level of investment as it increases from $\mathrm{I}_{1}$ to $\mathrm{I}_{2}$ as shown in the MEI curve. The major drawback of the marginal efficiency theory is its neglect of the future costs associated with investment.

\subsection{Review of Interest Rates Policy in Nigeria}

Prior to the adoption of Structural Adjustment Programme in 1986, the Central Bank of Nigeria administratively pegged the interest rate with a view to facilitating socially optimum resource allocation, growth of the financial market and credit flows to preferred sectors. Between 1970s and the mid of 1980s different interest rates were applicable for different sectors of the Nigerian economy (Kolawole, 2013). This followed the assumption that the market rate would cause financial exclusion; especially for priority sectors if its application is universal for all sectors of the economy. Consequently, periodic adjustment of the prevailing rates of interest was carried out to engender growth in the key sectors of the Nigerian economy. Specifically, agriculture and industrial sectors received special attention as commercial banks' loans to these sectors are associated with preferential interest rates. Although nominal and real interest rates were low during the controlled interest rate regime the costs of these manifested in high inflation and financial disintermediation due to low savings and investments (Soludo, 2008).

The introduction of Structural Adjustment Programme (SAP) in 1986 following the recommendation of the International Monetary Fund (IMF) necessitated the deregulation of the Nigerian financial sector including interest rates. Consequent upon this, the interest rates become market-driven as the forces of demand and supply of funds rather than administrative fixing by monetary authorities were allowed to act as driving force for resource allocation. This caused an increase in the rates of interest compared to the repressed regime when it was administratively fixed by the monetary authorities. Between 1970 and 1979, interest rate averaged 6.8 percent and increased to 17.5 percent in 2005 (Kolawole, 2013). The Central Bank of Nigeria continued to manipulate the minimum rediscount rate (MRR) in response to overall changes in economic activities. In the first quarter of 1987, the Central Bank of Nigeria reduced the minimum rediscount to 12.5 percent with the objective of stimulating investment and growth of the economy (Eregha, 2010). This increased the demand for money for investment purposes.

The desire to moderate financial expansion necessitated an increase in the minimum rediscount rate. Specifically, the minimum rediscount rate was increased to 13.25 percent in 1989 (CBN, 2008). This caused variations in the rate of interest changed by different banks with newly licensed banks charging high interest rates compared to old and well-established banks. The CBN introduced quantitative easing in order to cushion the effect of global financial and economic meltdown on the Nigerian economy. Despite the measures employed, credit to the private sector declined and lending rates increased astronomically.

Additionally, the growth in government borrowing increases the crowding out of private sector credit due to upward trend in the interest rate. Despite the costs associated with the liberalization of interest rates in Nigeria, it generated some positive spillovers due to the prevailing moderate level of inflation. Soludo (2008) posits that from 1998 to 2006 inflation rate in Nigeria moderated significantly which enhanced the aggregate level of economic activities. Again, (Kolawale, 2013) asserts that the annual average rate of inflation declined from 12.5 percent in 2009 to 13.7 percent in 2010. The fluctuations in the rate of interest can affect the willingness of surplus spenders to part with liquidly and overall objective of financial intermediation by deposit money banks. 


\subsection{Review of Empirical Literature}

The relationship between interest rate and industrial sector productivity has received huge attention in the past studies. These studies predominantly anchor on neoclassical and Keynesian preference theories of interest rate which have generated mixed results.

Towase (2012) investigated the effect of bank credit on industrial sector performance in Nigeria. The study covered the period of 1975 to 2009 and using interest rate, commercial bank's loans and advances to industrial sector and inflation rate among others as explanatory variables. The estimation techniques employed include cointegration test and error correction model. Evidences from the result reveal that interest rate, commercial bank's loans and advances to the private sector and rate of inflation significantly impacts on the real gross domestic product, proxy for private domestic investment. The study suggested for the increase in the liquidity of the commercial banks to enable them foster long-term industrial sector performance.

Adeyemi and Olufemi (2016) assessed the determinants of capacity utilization in the manufacturing sector in Nigeria. The study spanned through the period of 1975 to 2008. The real interest rate, electricity generation, inflation rate and fixed factor formation in manufacturing sector were included in the model as regressors. The data obtained from CBN Statistical Bulletin and Annual Abstract of Statistics of National Bureau of Statistics (NBS) was analyzed using cointegration and error correction model (ECM). It was evident from the findings that consumer's price index and fixed capital formation in manufacturing sector have positive relationship with capacity utilization in manufacturing sector. The study also reveals that interest rate at large 2 is negatively related with capacity utilization in manufacturing sector. Therefore, the study suggested that efforts should be geared towards boosting electricity generation in order to accelerate the productive capacity of the manufacturing firms.

Imoisi et al. (2012) investigated the effects of interest rate and exchange rate on Nigerian economy between 1975 and 2008 using secondary data obtained from CBN Statistical Bulletin. The analytical techniques employed include Ordinary Least Square (OLS) cointegration test and error correction technique. The findings show that exchange rate and interest rate impacted negatively on the Nigerian economy during the study period. However, the study recommends for the existence of a competitive and stable exchange rate that will stimulate investment and facilitate industrial expansion in Nigeria.

Peersman and Smets (2002) assessed the effects of changes in monetary policy on selected industries in the Euro area from 1980 to 1998. Specifically, eleven industries of seven Euro area countries were selected for the study. The reduced- form output equation was used as an analytical framework and the data sourced from the Organization of Economic Cooperation and Development (OECD) database was analyzed with the application of vector autoregressive (VAR) technique. Evidences from the results indicate that interest rate heightening on the average generated a greater significant negative impact on industrial output in recessions than in booms. The study concludes that financial accelerator mechanism is more effective during periods of recession.

Aiyedogbon and Anyanwu (2016) examined the macroeconomic determinants of industrial development in Nigeria between 1981 and 2013. The study included exchange rate, consumer price index, broad money supply, and interest rate among others in the model as determinants of industrial production index. The estimation technique adopted by the study is Ordinary Least Squares (OLS) and the result reveals that exchange rate, interest rate, and foreign direct investment impacted positively on industrial production index while consumer price index, broad money supply and credit to manufacturing sector impacted negatively on industrial sector performance. The study recommended for the determination of effective and efficient broad money supply capable of enhancing the availability of credit to the manufacturing sector and equally controls interest rate to stimulate investment.

Dada (2015) evaluated the effect of financial sector reforms on the growth of manufacturing sector in Nigeria. Real rate of interest to manufacturing sector and credit to manufacturing sector among others were used as measures of financial sector reform. The study covered the period of 2001 to 2011 using time series data from the statistical bulletin of the Central Bank of Nigeria. The relationship between the variables was estimated with the application of cointegration and granger causality techniques. The result shows that real interest rate generated significant positive influence on the growth of manufacturing sector. Additionally, other measures of financial sector reform generated positive effects on the growth of manufacturing sector during the period under investigation. The study suggested for the building up of the manufacturing sector though improvement of the existing infrastructures and protection of the local industries.

Aghion, Farhi and Kharroubi (2015) investigated the role of counter-cyclical interest rate on growth of industrial sector. Panel data for cross-industry, cross-country was used to ascertain whether real short-term interest rates and industrylevel measures of financial constrain affect industrial growth. A multivariate regression model was adopted for the study and the findings reveal that the counter-cyclical real short-term interest rate has significant and positive effect on the average annual growth of the industrial labour productivity. It was evident from the results that the effects of the variables on the industrial growth are more significant in the period of recession than during expansion period.

Dedola and Lippi (2000) examined the effect of monetary transmission mechanism on 21 manufacturing industries in five Organization for Economic Cooperation and Development (OECD) countries. Specifically, the OECD countries selected include United States, Germany, France, United Kingdom and Italy. The data collected from the OECD countries were analyzed using vector autoregressive (VAR) model. The findings show that interest payment burden is significant in explaining changes 
in the industry output. Similarly, other credit channel variables as well as investment-intensity significantly influenced crossindustry growth in the selected countries.

\section{Materials and methods}

\subsection{Model Specification}

This study employs an Autoregressive Distributed Lag (ARDL) model with the disaggregation of interest rate into prime lending rate (PML) and deposit rate (DPR) and inclusion of monetary policy rate (MPR) and cash reserve ratio (CRO) as explanatory variables. On the other hand, the industrial output served as the response variable. The model is expressed in a functional form as:

INO = $\mathrm{f}(\mathrm{PML}, \mathrm{DPR}, \mathrm{MRR}, \mathrm{CRO})$

The ARDL model of the functional equation in equation (1) is formalized as:

$$
\begin{aligned}
\operatorname{InINO}_{\mathrm{t}} & =\mathrm{P}_{0}+\pi_{1} \mathrm{InINO}_{\mathrm{t}-1}+\pi_{2} \mathrm{PML}_{\mathrm{t}-1}+\pi_{3} \mathrm{DPR}_{\mathrm{t}-1}+\pi_{4} \mathrm{MRR}_{\mathrm{t}-1}+\pi_{5} \mathrm{CRO}_{\mathrm{t}-1}+\sum_{i=1}^{m} z_{1} \Delta \operatorname{InINO} O_{t-1}+\sum_{i=1}^{m} z_{2} \Delta P M L_{t-1}+ \\
\sum_{i=1}^{m} z_{3} \Delta D P R_{t-1} & +\sum_{i=1}^{m} z_{4} \Delta M P R_{t-1}+\sum_{i=1}^{m} z_{5} \Delta C R O_{t-1}+\mathrm{e}_{1 \mathrm{t}}
\end{aligned}
$$

Where: INO, PML, DPR, MRR and CRO are Output of industrial sector, prime lending rate, deposit rate, monetary policy rate and cash reserve ratio. $z_{0}$ is constant parameter, $\pi_{1}-\pi_{5}$ are long run multipliers while $z_{1}-z_{5}$ are short run dynamic parameters of the regressors. In, $\mathrm{e}_{1 \mathrm{t}}$ are respectively natural logarithm notation and random disturbance term while $\mathrm{m}$ and $\Delta$ are optimal lag length and first difference operator.

\subsection{Nature of Data and Sources}

Annual time series data on the underlying variables are culled from the Central Bank of Nigeria Statistical Bulletin over the period 1987-2016. The description of datasets is provided in Table 1.

\begin{tabular}{|c|c|c|}
\hline Variable & Data Type & Source \\
\hline Industrial Output (INO) & Annual time series data, 1987- & Central Bank of Nigeria Statistical \\
& 2016 & Bulletin, CBN (2016). \\
\hline Prime lending rate (PML)) & Annual time series data, 1987- & Central Bank of Nigeria Statistical \\
& 2016 & Bulletin, CBN (2016). \\
\hline Deposit rate (DPR) & Annual time series data, 1987- & Central Bank of Nigeria Statistical \\
& 2016 & Bulletin, CBN (2016). \\
\hline Monetary policy rate (MPR) & Annual time series data, 1987- & Central Bank of Nigeria Statistical \\
& 2016 & Bulletin, CBN (2016). \\
\hline Cash reserve ratio (CRO) & Annual time series data, 1987- & Central Bank of Nigeria Statistical \\
& 2016 & Bulletin, CBN (2016). \\
\hline
\end{tabular}

Table 1: Description of the datasets

Source: Researcher's compilation (2017)

\subsection{Estimation Techniques}

This paper employed the Autoregressive Distributed Lag (ARDL) model developed by Pesaran and Shin (1999) in analyzing the long-term impacts of each of the explanatory variables on the dependent variable. One of the reasons for the utilizing the ARDL among others is based on its robustness for estimating models with small and relatively large observations. More importantly, the ARDL is applied not withstanding whether are integrated of the same order or fractionally integrated. Thus, the variables under investigation could be I (0), I (1) or a combination of I (0) and I (1) variables. Again, by allowing for the inclusion of the lagged variables including the lag value of the response variable as independent variable, the ARDL is adjudged to provide opportunity for overcoming the problem of endogeneity often associated with time series data. The stationarity and cointegration tests undertaken in the course of this study are explained below:

\subsection{Stationarity test}

The stationarity process of each of the economic time series utilized in this paper is captured using the Augmented Dickey Fuller approach to unit root test as proposed by Dickey and Fuller (1981). This stationarity approach was applied in testing the null hypothesis of a unit root against the alternative hypothesis of no unit root at the conventional 5 percent level. For each of the variables to be included into the model, it is expected to be I(0) or I(1), but not I(2). The specification of the unit root model is provided as: 


$$
\Delta Q_{t}=p_{0}+p_{1} \mathrm{Q}_{\mathrm{t}-1}+\sum_{i=1}^{n} h_{i} \Delta Q_{\mathrm{t}-\mathrm{i}}+u_{\mathrm{t}}
$$

Where: $\mathrm{Q}_{\mathrm{t}}=$ variable being investigated, $p_{1}$ and $h_{i}=$ coefficient of the variable, $\mathrm{n}=$ lag length, $\Delta=$ First difference operator and $\mathrm{u}_{\mathrm{t}}=$ white noise

\subsection{Cointegration test}

This paper used bounds test approach to cointegration to examine if long relationship exists among the underlying variables. In this procedure, the null hypothesis of no cointegration was tested against the alternative hypothesis of cointegration with the application of Wald test or F-test. The formalization of the model for the bounds test is as follows:

$y_{t}=\alpha+\sum_{i=1}^{k} \beta_{i} x_{i}+\varepsilon_{t}$

Where $\alpha_{0}$ is the intercept, $x_{i, t}$ is the vector of regressors. $\mathrm{k}$ and $\varepsilon_{t}$ are the optimal length and white noise respectively.

\section{Results and Discussion}

\subsection{Stationarity Test}

The outcome of the Augmented Dickey-Fuller test for unit root for each of the variables is summarized in Table 2.

\begin{tabular}{|c|c|c|c|c|c|}
\hline \multirow{2}{*}{ Variable } & \multicolumn{2}{|c|}{ ADF statistics } & \multicolumn{2}{c|}{ Prob. Value } & \multirow{2}{*}{ Order of integration } \\
\cline { 2 - 5 } & Levels & 1st difference & Levels & 1st difference & \\
\hline Log(INO) & -1.914 & -6.502 & 0.6213 & 0.0001 & $\mathrm{I}(1)$ \\
\hline PML & -4.016 & -7.177 & 0.0215 & 0.0000 & $\mathrm{I}(0)$ \\
\hline DPR & -3.653 & -6.895 & 0.0425 & 0.0000 & $\mathrm{I}(0)$ \\
\hline MPR & -3.989 & -3.695 & 0.0206 & 0.0455 & $\mathrm{I}(0)$ \\
\hline CRO & -1.885 & -4.937 & 0.6360 & 0.0024 & $\mathrm{I}(1)$ \\
\hline
\end{tabular}

Table 2: Augmented Dickey-Fuller (ADF) stationarity test result

Source: Researcher's Computation using Eviews 9

The stationary test result summarized in Table 2 reveals that prime lending rate (PML), deposit rate (DPR), and monetary policy rate (MPR) are stationary at levels or integrated of order zero [I(0)] while industrial output (INO) and cash reserve ratio (CRO) are difference stationary or integrated of order one [I(1)]. How ever, none of the variables is integrated of order two [I(2)], indicating that they satisfy the requirement to be included in the ARDL model as suggested by Pesaran and Shin (1999).

\subsection{Cointegration test}

This paper applied the bounds test procedure to cointegration to test the null hypothesis of no long run relationship against the alternative hypothesis of long run relationship. The result is reported in Table 3.

\begin{tabular}{|c|c|c|}
\hline \multicolumn{3}{|c|}{ ARDL Bounds Test } \\
\hline \multicolumn{3}{|c|}{ Null Hypothesis: No long-run relationships exist } \\
\hline Test Statistic & Value & $\mathrm{K}$ \\
\hline F-statistic & 9.881636 & 4 \\
\hline Significance & Critical Value Bounds \\
\hline $10 \%$ & I0 Bound & I1 Bound \\
\hline $5 \%$ & 2.45 & 3.52 \\
\hline $2.5 \%$ & 2.86 & 4.01 \\
\hline $1 \%$ & 3.25 & 4.49 \\
\hline & 3.74 & 5.06 \\
\hline
\end{tabular}

Table 3: Result of ARDL based bounds test cointegration procedure

NB: $\mathrm{k}$ implies number of exogenous variables

Source: Researcher's Computation using Eviews 9

Table 3 shows the bounds test result for of long run relationships among the underlying variables. The result shows that the calculated F-statistics (9.88) exceeds the upper bounds critical value (4.01) at five percent level. This implies that long run 
relationships exist among the variables. Hence, the null hypothesis that no long run relationship exists is rejected. Sequel to the outcome of the bounds test, the long run parameters of the exogenous variables is estimated.

\subsection{Estimation of the ARDL model}

Owing to the stationarity process [I(0) and I(1)] in section (4.1) and evidence long run relationship in section (4.2), this paper employed the Schwarz Information Criterion (SIC) for estimating the ARDL process $(4,1,0,1,0)$. The long run parameters of the exogenous variables are reported in Table 4.

\begin{tabular}{|c|c|c|c|c|}
\hline \multicolumn{5}{|c|}{ Dependent variable: Log(INO) } \\
\hline Variable & Coefficient & Std. Error & t-Statistic & Prob. \\
\hline PML & $0.320461^{*}$ & 0.171008 & 1.873956 & 0.0805 \\
\hline DPR & $-0.125183^{*}$ & 0.065280 & -1.917646 & 0.0744 \\
\hline MPR & $-0.220346^{* *}$ & 0.097356 & -2.263293 & 0.0389 \\
\hline CRO & -0.029530 & 0.065432 & -0.451311 & 0.6582 \\
\hline C & $8.238696^{* * *}$ & 2.076158 & 3.968241 & 0.0012 \\
\hline \multicolumn{5}{|c}{ R-Squared $=0.98$} \\
F-statistics $=142.53$ \\
Prob(F-stat.) $=0000$ \\
\hline
\end{tabular}

Table 4: Long run coefficients of the exogenous variables

NB: ***, $* *, *$ denote significant at $1 \%, 5 \%$ and $10 \%$ levels.

Source: Researcher's Computation using Eviews 9

Table 4 presents the estimated long run coefficients of the exogenous variables. The result shows that at 10 percent level, prime lending and deposit rate respectively have positive and negative effects on industrial output. Although positive impact of prime lending on the productivity of the industrial sector is noteworthy as it deviated from the a priori expectation, it authenticated past studies (Aiyedogbon and Anyanwu, 2016; and Dada, 2015), but conflicted with Imoisi (2012). However, this could be attributed to the poor development of the financial system and inconsistencies that often characterize the implementation of monetary policy in Nigeria. The negative effect of deposit rate on industrial output conflicts with the expected outcome as increase in deposit rate is intended to provide incentive for mobilizing savings from surplus spenders. The result also reveals that monetary policy rate exerts significant negative influence on industrial output at 5 percent level during the study period. A percentage increase in monetary policy rate contracts industrial output by 0.22 percent. This finding is consistent with the hypothesized negative relationship between the two variables. The probability value $(0.0000)$ of the F-statistics (142.53) also attest to the robustness ARDL model as it revealed that the exogenous variables are jointly significant in accounting for changes in industrial output. The coefficient of determination (0.98) reveals that 98 percent of the systematic variations in industrial output are accounted by changes in exogenous variables. This is suggestive that the model well fitted as the observation cluster closely to the fitted regression line.

\subsection{Diagnostics Tests}

The reliability of the estimated ARDL model is examined through the diagnostics tests. Specifically, higher order serial correlation and autoregressive conditional heteroscedasticity tests were applied to determine if the errors are serially correlated and have a constant variance. In addition to these, the model is subjected to normality test to check whether the errors are normally distributed. The results of these tests are reported in Table 5.

\begin{tabular}{|c|c|c|}
\hline Test type & Test stat. & p-value \\
\hline Serial correlation (Breush-Godfrey LM test) & $\mathrm{X}^{2}$-statistics & 0.7593 \\
\hline Heterskedasticity test (ARCH test) & $\mathrm{X}^{2}$-statistics & 0.9155 \\
\hline Normality test & Jacque-Bera stat. & 0.7162 \\
\hline
\end{tabular}

Table 5: Diagnostic tests results

Source: Researcher's estimation from E-views 9

The diagnostics test result reported in Table 5 shows that the model is not serially correlated at 5 percent level given that the probability value $(0.7593)$ of the chi-square $\left(\mathrm{x}^{2}\right)$ statistic of the Breusch-Godfrey Lagrange Multiplier (LM) test is greater than 0.05. Similarly, the ARCH test result indicates that the variance of the random variable is homoscedastic at 5 percent level as the probability value $(0.9155)$ of its associated square $\left(\mathrm{x}^{2}\right)$ statistic exceeds 0.05 . The probability value (0.7162) of the Jarque-Bera Statistics indicates that the errors are normally distributed. The outcomes of the diagnostics authenticate the reliability of the estimated model and its usage for macroeconomic prediction with high level of precision. 


\section{Concluding Remarks and Policy Recommendations}

\subsection{Concluding Remarks}

Interest rate policy has been adjudged as the integral part of monetary policy package geared towards influencing real sector performance and diversification of the domestic economy. This stems from the popular assumption that invested funds are borrowed. The findings from the empirical analysis reveal that the prime lending rate and industrial output are positively related in the long. However, changes in monetary policy rate and deposit rate are found to contract the productivity of the industrial in the long run. It can be concluded from the findings that the industrial sector in Nigeria seem not to be vulnerable to the variations in the market rate of interests. This paper equally demonstrates that the monetary policy rate often provided by the Monetary Policy Committee (MPC) tends to constitute a major constraint to effective performance of the industrial sector in the long run. The conclusion drawn from the negative impact of deposit rate on industrial output is that the deposit rate provided by Deposit Money Banks in Nigeria seems inadequate to mobilize savings from the surplus spending units for relending them to investors.

\subsection{Policy Recommendations}

- $\quad$ The Central Bank of Nigeria should ensure that interest rate deregulation is frequently monitored and primarily tailored towards ensuring that the prevailing market rate of interest provides opportunity for improved performance of the industrial sector.

- $\quad$ The Monetary Policy Committee (MPC) in Nigeria should always ensure that the monetary policy rate (MPR) prioritizes the availability investment-accommodating interest rate.

- Interest rate policy should be incorporated into the overall policy package of stimulating the productivity of the industrial sector.

- $\quad$ Deposit Money Banks should strive to mobilize adequate savings from surplus spenders by offering them deposit rate capable of inducing the savers to increase their savings and boost the availability of loanable funds.

\section{References}

i. $\quad$ Acha I. A. \& Acha C. K. (2011). Interest Rates in Nigeria: An Analytical Perspective. Research Journal of Finance and Accounting, IISTE, 2(3).

ii. Adegbie, F.F and Adeniji, A.A (2013). Globalization and Corporate Social Investment Towards Productivity Enhancement and Resolution of Distress in Nigerian Economy. International Journal of Advancement in Management Science, 3(1),105-113.

iii. Adeyemi, P.A. \& Olufemi, O. B. (2016). The Determinants of Capacity Utilization in the Nigerian Manufacturing Sector. Journal of Economics and Sustainable Development, 7(5).

iv. Aghion, P., Farhi, E., \& Kharroubi, E. (2015). Liquidity and growth: the role of counter-cyclical interest rates. BIS Working Paper No. 489. Available at SSRN: https:/ / ssrn.com/ abstract=2564266

v. Aiyedogbon, J. O. \& Anyanwu, S. O. (2016). Macroeconomic Determinants of Industrial Development in Nigeria. Nile Journal of Business and Economics, 1(1), 37-46.

vi. $\quad$ Ajilore, O. T. (2015). Factors that Influence Interest Rate Decisions in Nigeria. CBN Bullion No. 47.

vii. Calomiris, C. W., Himmelberg, C. P., \&Wachtel, P. (1995). Commercial paper, corporate finance, and the business cycle: a microeconomic perspective. In Carnegie-Rochester Conference Series on Public Policy (Vol. 42, pp. 203-250). NorthHolland.

viii. Dada, O. D. (2015). Effect of Financial Sector Reforms on the Growth of Manufacturing Sector in Nigeria. International Journal of Banking, Finance, Management \& Development Studies, 1(6), 86-98.

ix. Dedola, L., \& Lippi, F. (2000). The monetary transmission mechanism: evidence from the industries of five OECD countries (No. 2508). CEPR Discussion Papers.

x. Dickey, D. A., \& Fuller, W. A. (1981). Likelihood ratio statistics for autoregressive time series with a unit root. Econometrica: Journal of the Econometric Society, 1057-1072.

xi. Edeme, R. K., \& Karimo, T. M. (2014). Economic Liberalization and Industrial Sector Performance in Nigeria-A Marginal Impact Analysis. International Journal of Development and Emerging Economics. 2(4), 43-59.

xii. Eregha, P. B. (2010). Interest rate variation and investment determination in Nigeria. International Business Management, 4(2), 41-46.

xiii. Imoisi, A. I., Chika, U. P., \& Moses, O. L. (2012). An Analysis of Interest and Exchange Rates Effect on the Nigerian Economy: 1975-2008. Asian Economic and Financial Review, 2(6), 648.

xiv. Kolawole, B. O. (2013). Institutional reforms, interest rate policy and the financing of the agricultural sector in Nigeria. European Scientific Journal,9(12).

xv. McKinnon, R.I., (1973). Money and Capital Market in Economic Development. Washington, DC: The Brookings Institution.

xvi. $\quad$ Nweze, C.(2010). CBN Issues New Rules on Risk Management in Gbenga O. (Ed.) The Nation, July 14, 2010. Lagos: Vintage Press Ltd. 
xvii. Peersman, G. and Smets, F. (2002). The industry e2ects of monetary policy in the Euro area. European Central Bank, Working paper no. 165

xviii. $\quad$ Pesaran, M. H. and Shin, Y. (1999). An Autoregressive Distributed Lag Modelling Approach to Cointegration Analysis' in S Strom, (ed.), Econometrics and Economic Theory in the 20th Century: The Ragnar Frisch Centennial Symposium, Cambridge: Cambridge UP.

xix. $\quad$ Simon-Oke, O. O., \& Aribisala, S. E. (2010). Exchange Rate Deregulation and Industrial Performance: An Assessment (1975-2006). African Research Review, 4(2).

xx. Smets, F. (2002). The Industry Effects of Monetary Policy in the Euro Area. European Central Bank Working Paper No. 165.

xxi. Soludo, C. C. (2008). Achieving Interest Rate and Exchange Rate stability in Nigeria Options and relevance. Research Department, CBN, Abuja.

xxii. Tawose, J. O. B. (2012). Effects of bank credit on industrial performance in Nigeria. International Business and Management, 4(2), 158-168. 